\title{
Physical Condition Profile of Handball Athletes
}

\author{
Basiran Basiran*, Ridha Mustaqim, Witri Fandayani \\ Faculty of Sport and Health Education \\ Universitas Pendidikan Indonesia \\ Bandung, Indonesia \\ *basiran@upi.edu
}

\begin{abstract}
The physical ability for a player is a requirement to showcase their work. If the player's physical condition is good, there is an increase in performance in a sports branch. The purpose of this research is to identify the level of physical condition in the players of the Bandung handball team. The method of study used is a descriptive method. The population of this research is the player of the Bandung district handball team as many as 18 people. All populations are made samples (total sampling). This research instrument is a physical condition test, consisting of 6 (six) test items: Modified Sit and Reach, Sit-Up, 20 meter run, Shuttle Run, Vertical Jump and Bleep Test. Based on the results of data analysis and discussion of research results obtained, it can be concluded; a) There is not a single player in the district of Bandung handball in the category of good and good, b) level of physical condition players team that belongs to the category there are enough 6 players if calculated in percent of $33.33 \%$, c) Level of condition player of the handball team Bandung district which belongs to the category of less there $\mathbf{1 0}$ players if calculated in the percent of $55.56 \%$, d) the level of the player's condition of the team of Bandung district handball that belongs to the category of very less there 2 Player if calculated in percent of $11.11 \%$. Overview In general can be said that the physical condition level of players of the Bandung district handball team is in the category less.
\end{abstract}

Keywords: handball, physical condition, profile

\section{INTRODUCTION}

One of the sports branches that are currently favoured among the people of Indonesia and even the world is a handball sports branch. It can be seen by many things, one of them is a championship or tournament of both regional scale, national and international. In addition, the introduction of handball sports in the national curriculum in both elementary school to high school to higher education level increasingly increasing the society animo in the love of Handball sports branch The. Handball is a team sport in which two teams with 7 players each (6 players and 1 goalkeeper) in which each team tries to insert a ball into the opponent's goal. The ball is thrown, or fired with one or two hands. In this game it is more precisely called as a combination game between basketball games and handball games, because of the basic technique skills when playing the ball by hand more like a basic technique of basketball sports [1].

Game rules Handball: The game time for all teams with 16 or more age players is 2 rounds each for 30 minutes with a 10minute break and a field measuring $40 \mathrm{~m} \times 20 \mathrm{~m}$ with a dividing line in the centre and the goal at Middle of both short side and penalty is done from a distance of 7 meters, the ball used is smaller than the football is size 3.2 and 1 while the game time for the youth team (12-16 years) is $2 \times 25$ minutes, and $2 \times 20$ minutes for the age of 8-12 years for the player above 16 years old and the teen breaks between rounds is 10 minutes [2]. Handball became famous throughout the country due to the creation of the International Handball Federation (IHF) pioneer in 1946 which was declared by eight countries: Denmark, Finland, France, Netherlands, Norway, Poland, Switzerland, and Sweden. Until 2003 IHF had a total of 150 participants with 80,000 clubs and 19 million men and women athletes. The Indonesian Handball Association (ABTI) is the parent of the handball organization in Indonesia, which became a member of the International Handball Federation (IHF) since 2007. According to the notary deed on the establishment of the Indonesian Handball Association in front of the notary Lilik Kristiwati, S.H., the Indonesian Handball Association officially stood on 16 August 2007. On June 5, 2009, ABTI was officially known as the Full Member International Handball Federation (IHF) headed by Arie P. Ariotedjo.

ABTI (Asosiasi Bola Tangan Indonesia) is an association that takes care of everything related to handball at the national level, including arranging early childhood coaching, beach handball, human resources trainers and referees, competitions and others. Almost every region in Indonesia has a club or regional caretaker and a branch manager listed in ABTI, and from each area has early childhood coaching. In 2016 handball followed the PON (National Sports Week) exhibition in West Java where the West Java team could reach gold in the men's category. Along with the rapid multi-event and also the development of handball at the national level then in the year 2018, especially in the area of West Java, Handball Sports Branch took part of several sports branches played in PORDA (Pekan Regional sports) Bogor regency. After the official follow the PORDA Handball sports Branch held an event test in the form of a qualifying round PORDA.

For the city or district that passes in the PORDA qualifying round is entitled to join the PORDA event, including: 
mobility that is done systematically and progressively enhanced to maintain or improve the degree of physical fitness to achieve work ability to the expected objectives that are adjusted to the needs of each sport branch $[7,8]$. Pasurney and Sidik further explains the sense of physical ability, namely the understanding of physical conditions in sports is all physical abilities that determine the achievement of the realization through personal ability (motivation \& ability) [9]. With all the physical abilities, of course, the physical elements of the rides vary from one readiness to a branch's physical condition to another to perform better [10]. The training of aspects of physical conditions is an important factor of the part of the coaching process to achieve the maximum training objectives, of course, through a systematic and sustainable development so that the exercise training Performed on athletes increasingly increasing and the goal of training will be achieved optimally.

The results of this research are expected to be a referral material, especially for Indonesian University of education institutions and generally for the community lovers of handball sports. In addition, the external research that will be generated from this field of expertise group is a scientific article product research results that will be loaded or published in an accredited National Journal or reputable international journals.

The real handball game is a blend of soccer games and basketball games, so the rules used in handball games also take much more than the two types of games. Likewise, about the principles in the game, it is also more than a lot of things to take or even a mix of football games and basketball games. Soccer and basketball games are a very popular game played around the world including this in Indonesia, so we also know and understand, how to play games and playing football and basketball. Similarly, in a handball game, that game shape and how to play it like in the soccer and basketball games. It means that the elements are in the game of handball, mostly in football and basketball games.

In the situation of handball games, each player must be able to play the ball well. The way to play the ball according to its name is handball, which is by hand [11]. More details that in this handball game, each player is required to be able to (skilfully) play the ball with his hands. Skill playing ball with this hand, is one of the basic capital for each player in the handball game. But we must remember that the handball is a team game, so that the skills of playing balls individually will not mean that they are not combined with the good cooperation between the fellow Seregu. Basically that a harvest must be able to work with the Seregu friends, must have the skills to play the ball, in order to win the game in a handball game. As for mastering the ball or playing a ball together with a team mates with the aim of being hard to take over or taken on an opponent, need a certain way called techniques.

Every handball athlete must have a very good physical condition, because this handball game is very vulnerable to the loud clash between players. Not infrequently if the player does not have a prime physical condition will be injured and the level of freedom is high $[11,12]$. Therefore the role of physical condition is needed by every handball athlete. Physical conditions must be developed through good, systematic and well-planned training. In a physical condition training pattern,
Good physical quality will sustain directly to the quality of training is a training process to develop the ability of physical 
study using test techniques. The method in question is to collect data about the physical condition of the player of the Bandung Regency.

The population in this study was the player of the Bandung district handball team of 18 people. The samples in this study were taken using total sampling or the entire population was used as sample research.

The instrument for measuring the physical condition in this study uses several instruments:

- Flexibility using Modified Sit and Reach test,

- Speed using 20 meter sprint run test,

- Agility using Shuttle Run test,

- Stomach resistance using Sit up test,

- Leg power using Vertical Jump test,

- Cardiovascular using Bleep test.

In this descriptive study is only looking for a real picture of the physical condition of the team of handball athletes. Data retrieval is taken from athlete's test before the trigger cab process, so it is expected in the results of this research can be used as a reference for training programs and development of handball athletes in the future.

Data collection techniques are by observation. To facilitate the analysis of data in this study, the authors used SPSS 21 for Windows Program [15].

This activity will be held for 3 months. The details of the activities as a whole are as follows:

TABLE II. RESEARCH PROCEDURE

\begin{tabular}{|l|l|l|l|l|}
\hline \multirow{2}{*}{ No } & \multicolumn{1}{|c|}{ Activity Description } & \multicolumn{3}{|c|}{ Execution time (months) } \\
\cline { 2 - 5 } & \multicolumn{1}{|c|}{$\mathbf{1}$} & $\mathbf{2}$ & $\mathbf{3}$ \\
\hline 1 & $\begin{array}{l}\text { Preparation, planning and } \\
\text { proposal drafting }\end{array}$ & $\mathrm{X}$ & & \\
\hline 2 & Test execution and data retrieval & & $\mathrm{X}$ & \\
\hline 3 & Data processing and analysis & & $\mathrm{X}$ & \\
\hline 4 & Research report generation and & & & $\mathrm{X}$ \\
\hline 5 & $\begin{array}{l}\text { Seminar, evaluation } \\
\text { improvement of research }\end{array}$ & $\mathrm{X}$ \\
\hline 6 & $\begin{array}{l}\text { Submission of research reports } \\
\text { and publications on accredited } \\
\text { national journals and international } \\
\text { seminars }\end{array}$ & & $\mathrm{X}$ \\
\hline
\end{tabular}

\section{RESULTS AND DISCUSSION}

The data obtained from the test and measurement results are still raw scores, so that the data has meaning it should be processed and analysed statistically. Arikunto explains that drawing research conclusions should be based on data obtained in research activities [16].

Based on the results of data processing and analysis, the conclusion of the study is to test the physical condition of the player in the hands of Bandung District team there are 6 players that belong to the category enough with a percentage of $33.33 \%$, 10 players who belongs to the category less with a researchers used a descriptive research method. Because on research does not carry out control and manipulation of research variables. To obtain the appropriate data, then in this 
percentage of $55.56 \%$ and 2 players belonging to the category very less than 18 players who take the test.

TABLE III. TEST RESUlT PHYSICAL CONDITION ATHLETES HANDBALL TEAM BANDUNG DISTRICT

\begin{tabular}{|c|c|c|c|c|c|c|c|c|}
\hline \multirow[b]{2}{*}{ No } & \multirow[b]{2}{*}{ Name } & \multirow[b]{2}{*}{ TB/BB } & \multicolumn{6}{|c|}{ Result } \\
\hline & & & Sit and Reach & Sit Up 2' & $\begin{array}{c}\text { Shuttle Run } \\
8 m x 5\end{array}$ & $20 \mathrm{~m}$ & Bleep Test & $\begin{array}{c}\text { Vertical } \\
\text { Jump }\end{array}$ \\
\hline 1 & Bagus Ade & $171 / 59$ & 26 & 63 & 12,34 & 3,16 & 40,2 & 47 \\
\hline 2 & M.Irvan & $175 / 60$ & 28 & 62 & 12 & 3,27 & 40,5 & 52 \\
\hline 3 & Julinur & $164 / 65$ & 17 & 120 & 11,82 & 3,1 & 55,7 & 50 \\
\hline 4 & Andrew & $171 / 65$ & 26 & 103 & 10,32 & 2,98 & 54,1 & 43 \\
\hline 5 & Andriyana & $175 / 62$ & -5 & 80 & 12,09 & 3,18 & 44,8 & 45 \\
\hline 6 & Agung Dwi J & $167 / 57$ & 24 & 95 & 11,61 & 3,02 & 50,4 & 54 \\
\hline 7 & Hendri Kibo & $173 / 68$ & 42 & 87 & 11,48 & 3,25 & 50,2 & 52 \\
\hline 8 & Hanif S & $171 / 61$ & 34 & 80 & 11,74 & 3,09 & 50,4 & 47 \\
\hline 9 & Abdul Aziz & $168 / 61$ & 19 & 85 & 11,84 & 3,28 & 54,8 & 45 \\
\hline 10 & Alfathier & $166 / 60$ & 32 & 70 & 11,37 & 3,12 & 50,6 & 52 \\
\hline 11 & Angga Sidik & $166 / 59$ & 36 & 75 & 11,45 & 2,84 & 48,5 & 48 \\
\hline 12 & Yusup Maulana & $165 / 60$ & 20 & 73 & 11,42 & 3,27 & 40,2 & 45 \\
\hline 13 & Rahmat Male & $171 / 62$ & 35 & 90 & 11,48 & 3,09 & 48,5 & 53 \\
\hline 14 & Kiki Sp & $169 / 58$ & 36 & 82 & 12,13 & 3,2 & 57,6 & 48 \\
\hline 15 & Yusuf A & $165 / 53$ & 20 & 80 & 12,44 & 3,11 & 46,8 & 58 \\
\hline 16 & Jeni F & $168 / 60$ & -2 & 80 & 11,84 & 3,15 & 51,4 & 44 \\
\hline 17 & Ragil H & $160 / 55$ & 19 & 72 & 11,09 & 3,19 & 47,4 & 51 \\
\hline \multirow[t]{3}{*}{18} & Damas & $170 / 72$ & 42 & 90 & 13,23 & 3,36 & 45,4 & 55 \\
\hline & \multicolumn{2}{|l|}{ Total } & 449 & 1487 & 211,69 & 56,66 & 877,5 & 889 \\
\hline & \multicolumn{2}{|l|}{ Average } & 25 & 83 & 11,76 & 3,14 & 48,75 & 49 \\
\hline
\end{tabular}

The picture above is a test result conducted by the players of the Bandung district handball team. The players are given twice the opportunity to perform each test item, and the above data is the best result achieved in two occasions by each player.
The players are given twice the opportunity to perform each test item except the bleep test which is only done one Test time.

TABLE IV. InDIVIDUAL Physical Status ATHLETES HANDBALL TEAM BANDUNG DistRICT

\begin{tabular}{|c|c|c|c|c|c|c|c|c|c|c|c|}
\hline \multirow{2}{*}{ No } & \multirow{2}{*}{ Name } & \multirow{2}{*}{ TB/BB } & Flexibility & $\begin{array}{c}\text { Stomach } \\
\text { Resistance }\end{array}$ & Agility & Speed & $\begin{array}{c}\text { Cardio } \\
\text { Endurance }\end{array}$ & $\begin{array}{c}\text { Leg } \\
\text { Power }\end{array}$ & \multirow{2}{*}{$\sum$} & \multirow{2}{*}{ Average } & \multirow{2}{*}{$\begin{array}{c}\text { Individual } \\
\text { Physical } \\
\text { Status }\end{array}$} \\
\hline & & & $\begin{array}{l}\text { Sit and } \\
\text { reach }\end{array}$ & Sit Up 2' & $\begin{array}{c}\text { Shuttle } \\
\text { Run 8mx5 }\end{array}$ & $20 \mathrm{~m}$ & Bleep Test & $\begin{array}{c}\text { Vertical } \\
\text { Jump }\end{array}$ & & & \\
\hline 1 & Bagus Ade & $171 / 59$ & 6 & 2 & 4 & 6 & 2 & 4 & 24 & 4,00 & Less \\
\hline 2 & M.Irvan & $175 / 60$ & 6 & 2 & 4 & 4 & 2 & 6 & 24 & 4,00 & Less \\
\hline 3 & Julinur & $164 / 65$ & 4 & 8 & 6 & 6 & 8 & 6 & 38 & 6,33 & Enough \\
\hline 4 & Andrew & $171 / 65$ & 6 & 6 & 10 & 10 & 8 & 6 & 46 & 7,67 & Enough \\
\hline 5 & Andriyana & $175 / 62$ & 2 & 4 & 4 & 4 & 2 & 2 & 18 & 3,00 & Very Less \\
\hline 6 & Agung Dwi J & $167 / 57$ & 6 & 6 & 6 & 8 & 6 & 8 & 40 & 6,67 & Enough \\
\hline 7 & Hendri Kibo & $173 / 68$ & 10 & 6 & 6 & 4 & 6 & 6 & 38 & 6,33 & Enough \\
\hline 8 & Hanif S & $171 / 61$ & 8 & 4 & 6 & 6 & 6 & 4 & 34 & 5,67 & Less \\
\hline 9 & Abdul Aziz & $168 / 61$ & 4 & 4 & 6 & 4 & 8 & 2 & 28 & 4,67 & Less \\
\hline 10 & Alfathier & $166 / 60$ & 8 & 2 & 6 & 6 & 6 & 6 & 34 & 5,67 & Less \\
\hline 11 & Angga Sidik & $166 / 59$ & 8 & 2 & 6 & 10 & 6 & 4 & 38 & 6,33 & Enough \\
\hline 12 & Yusup M & $165 / 60$ & 4 & 2 & 6 & 4 & 2 & 2 & 20 & 3,33 & Very Less \\
\hline 13 & Rahmat Male & $171 / 62$ & 8 & 6 & 6 & 6 & 6 & 6 & 38 & 6,33 & Enough \\
\hline 14 & Kiki Sp & $169 / 58$ & 8 & 4 & 4 & 4 & 8 & 4 & 32 & 5,33 & Less \\
\hline 15 & Yusuf A & $165 / 53$ & 4 & 4 & 4 & 6 & 4 & 8 & 30 & 5,00 & Less \\
\hline 16 & Jeni $\mathrm{F}$ & $168 / 60$ & 2 & 4 & 6 & 6 & 6 & 2 & 26 & 4,33 & Less \\
\hline 17 & Ragil H & $160 / 55$ & 4 & 2 & 6 & 4 & 4 & 6 & 26 & 4,33 & Less \\
\hline 18 & Damas & $170 / 72$ & 10 & 6 & 2 & 2 & 2 & 8 & 30 & 5,00 & Less \\
\hline \multicolumn{3}{|c|}{ Total } & 108 & 74 & 98 & 100 & 92 & 90 & 562 & 93,67 & \\
\hline \multicolumn{3}{|c|}{ Average } & 6,00 & 4,11 & 5,44 & 5,56 & 5,11 & 5,00 & & 5,20 & \\
\hline \multicolumn{3}{|c|}{ TEAM Physical Condition Status } & Enough & Less & Less & Less & Less & Less & & Less & \\
\hline
\end{tabular}


test the physical condition more criteria to the characteristics of the sport of each branch both in terms of test items, instruments, and the types of tests.

\section{REFERENCES}

level of physical condition players of the Bandung Regency team belongs to the category less. This is because the physical condition is influenced also by factors affecting such as heredity, exercise, gender, age, body fat, and daily activities. While the factors influencing performance include physical, technical, tactics, mental and constitutional bodies.

Of course, by looking at this condition, it should be sought solution from the problem so that the level of physical condition player of the Bandung district handball team can increase from the results that the authors have done in this research, because when Level of physical condition is good then the increase in performance of Bandung district handball team will increase.

Reviewing its status as a player, the physical condition will need to be improved, especially the physical condition components that are felt less in order to achieve higher achievements later in the day. Results of the study can be concluded based on the results of the overall data analysis of the level of physical condition in the players of the Bandung district handball team, that the category achieved is less. This can be seen from the physical condition test result of modified sit and reach test, sit-up, shuttle run $8 \mathrm{~m} \times 5,20 \mathrm{~m}$ run, bleep test and vertical jump which shows that the overall player.

\section{CONCLUSIONS}

Based on the results of data processing and analysis, the conclusion of the results of this research turned out to profile the physical condition of the team's Handball Bandung District in general belongs to the category less.

Looking at the results of the physical condition of the player of the Bandung district handball team then, from the results of this research can be used as an overview of the level of physical condition players of the Bandung Regency handball team, so that the coach, trainer and The caretaker and its ranks can make efforts to improve the physical condition of the man's futsal player. For players of the Bandung district handball team, it is advisable to always keep the physical condition outside of the training program and do not be satisfied with the achievements that have been achieved, keep practicing hard so that the achievement is increased not only in the level, For the next research, the authors recommend to conduct research or
[1] G.G. Pennington, J.A. Day, J.N. Drowatzky and J.F. Hansan, "A measure of handball ability," Research Quarterly, vol. 38, pp. 247-253, 1967.

[2] International Handball Fenderation, Playing Rules and Referees Commission. 2007.

[3] L. Capranica and M.L. Millard-Stafford, "Youth sport specialization: How to manage competition and training?" Int. J. Sports Physiol. Perform, vol. 6(4), pp. 572-579, 2011.

[4] Harsono, Choaching dan Aspek-aspek Psikologis Dalam Choaching. Jakarta: Departemen Pendidikan dan Kebudayaan Dirjendikti, 1988.

[5] K.R. Wasaki, J.H. Zhang, Zuckerman and B.D. Levine, "Dose-response relationship of the cardiovascular adaptation to endurance training in healthy adults: How much training for what benefit?" J. Appl. Physiol, vol. 95, pp. 1575-1583, 2003.

[6] J.M. Wilson, J.P. Loenneke, E. Jo, G.J. Wilson, M.C. Zourdos, J.S. Kim "The effects of endurance, strength, and power training on muscle fiber type shifting," J Strength Cond Res, vol. 26(6), pp. 1724, 2012.

[7] M.S. Bray, J.M. Hagberg, L. Pérusse, T. Rankinen, S.M. Roth, B. Wolfarth and C. Bouchard, "The human gene map for performance and health-related fitness phenotypes: The 2006-2007 update," Med. Sci. Sports Exerc, vol. 41(1), pp. 35-73, 2009.

[8] A.D. Faigenbaum, R.L. Loud, J. O'Connell, S. Glover, J. O'Connell and W.L. Westcott, "Effects of different resistance training protocols on upper-body strength and endurance development in children," J. Strength Cond. Res, vol. 15(4), pp. 459-465, 2001.

[9] L.P. Pasurnay and D.Z. Sidik, Materi Penataran Pelatihan Fisik Tingkat Provinsi Se-Indonesia. Jakarta: Koni Pusat, 2006.

[10] D.C. Prasad and B.C. Das, "Physical inactivity: A cardiovascular risk factor,” Indian J. Med. Sci, vol. 63(1), pp. 33-42, 2009

[11] K. Bak and J.S. Koch, "Subtalar dislocation in a handball player," British Journal of Sports Medicine, vol. 25, pp. 24-25, 1991.

[12] J.J. Salinero, J.A. Vicen, J.D. Coso and C.G. Millán, "The influence of ankle dorsiflexion on jumping capacity and the modified agility t-test performance,” Eur. J. Sport Sci, vol. 14(2), pp. 137-143, 2014.

[13] A.M. Mostafavifar, T.M. Best and G.D. Myer. "Early sport specialisation, does it lead to longterm problems?" Br. J. Sports Med, vol. 47(17), pp. 1060-1061, 2013.

[14] D.G. Sale, "Neural adaptation in strength and power training. In Human muscle power, ed. N.L. Jones, N. McCartney and A.J. McComs, Champaign, IL Human Kinetics, pp. 281-305, 1986.

[15] S. Santoso, Menguasai SPSS 21 di era informasi. Jakarta: Elex Media Komputindo, 2013.

[16] Arikunto, Prosedur Penelitian Suatu Pendekatan Praktik. Jakarta: PT. Rineka Cipta, 2006 